\title{
THE ATTITUDES OF PETE PROGRAM APPLICANTS TOWARDS INFORMATION AND COMMUNICATION TECHNOLOGIES
}

\author{
Attila Varga ${ }^{1}$, Éva Bácsné Bába ${ }^{2}$, Gergely Ráthonyi ${ }^{3}$, Anetta Müller ${ }^{4}$ \\ ${ }^{1}$ Eszterházy Károly University, 3300, Eger, Leányka street 6. \\ ${ }^{1}$ varga.attila@uni-eszterhazy.hu \\ ${ }^{2,3,4}$ Debrecen University, 4032. Debrecen. Böszörményi street 138. \\ 2bacsne.baba.eva@econ.unideb.hu \\ ${ }^{3}$ rathonyi.gergely@econ.unideb.hu \\ ${ }^{4}$ muller.anetta@econ.unideb.hu
}

\begin{abstract}
As information and communication technology has permeated all aspects of life education cannot be considered an exception either. The schools of the 21st century require the use of the latest digital devices whose effectiveness is greatly determined by the motivation, ICT-related attitude, and the respective competences of teachers managing and directing the given teaching and learning process. Since P.E. also requires the use of information and communication devices it would be crucial that prospective teachers develop a positive attitude toward such equipment. The present research aims at exploring the attitudes of students applying to P.E. teacher programs at the Eszterházy Károly University toward such instruments and approaches. Additional research objectives include the exploration of potential correlation between the sex of the applicants and the respective attitudes. Our inquiry utilized the questionnaire method and the computer-based attitude scale was completed by a sample of 130 applicants in the 2016/2017 and the 2017/2018 academic years. Our research concluded that both men and women maintain a positive attitude toward the use of digital devices, or the tools of information and communication technology. Students representing both sexes consider the computer as a valuable learning device promoting the efficiency of the knowledge acquisition process. Furthermore, a significantly greater proportion of male respondents stated that they were capable of repairing computer problems emerging during use than that of their female counterparts. At the same time men are less apprehensive to use computers during instruction and this attitude appears to be an indispensable requirement for the application of ICT devices in class. The research can contribute to a deeper exploration of the given field along with performing a gap filling function as such examination has not yet been conducted among applicants to P.E. programs provided by higher education institutions in Hungary.
\end{abstract}

Keywords: Information and communication technologies, physical education, attitudes (JEL Classification: Z2, I23)

\section{INTRODUCTION}

Numerous studies are known that examine competences, competitive knowledge in different disciplines acquired during education (MÁTÉ - FENYVES 2016, TARNÓCZI et. al., 2017, MARKOS et. al. 2017). Other researches examine what activities and works do students undertake during their studies to enhance their professional knowledge (language, communication, ICT) and experience, which can be useful in increasing their competitiveness in the labor market (BÁCSNÉ et. al. 2018a, b).
Information and communication (henceforth ICT) devices are becoming increasingly prevalent nowadays. ICT technology can be defined as a variety of technological devices and sources facilitating the communication, production, storing, dissemination and management of information (BLURTON 1999). ICT devices became fully integrated into all aspects of life, their impact is felt virtually in all human activity and turned out to be the most essential means of information flow and acquisition. Such devices have taken over the previously prevalent role of traditional information 
sources, books, brochures, and the written or printed press (KOLTAY, 2010).

Since ICT tends to gain increasing priority both in the education sphere and on the labour market, students lacking digital literacy are at a significant disadvantage (PINEIDA, 2011; CZEGLÉDI, 2011). The importance of the potential of ICT and ICT literacy in the business sphere is clearly demonstrated by initiatives on the part of the EU and the US to integrate such technology and promote the instruction of relevant skills, competences, and attitudes into educational and further training programs. (MOLNÁR, 2011). In several countries or parts of the world ICT is considered to be a motivator behind changes and innovations impacting the education sphere Furthermore, numerous research projects focus on the educational application and integration of ICT devices highlighting the crucial role of teachers and their respective attitudes to the use of the given technology (ALBIRINI, 2006; BAYLOR and RITCHIE, 2002).

Research suggests that the efficiency or success of the educational implementation of ICT not only depends on the given infrastructure, that is devices and software, but on the professional background of the respective instructor. The ICT literacy level of the teacher can significantly determine the level of support he or she can give to students regarding the use of such technology during the learning process (YUEN et al. 2003; TEARLE, 2003; LAI- PRATT, 2004). International research results also prove that the competitiveness of teachers on the educational labour market requires inherent skills including the arrangement of the learning process, the willingness for continuous training, the ability to deal with the younger generation or address their needs along with the possession of ICT literacy to be deployed during the support of the learning effort (DAUVARTE, 2015). Consequently, physical education teachers and sports pedagogues of the future should be capable of integrating digital devices heretofore playing a crucial role in the instruction process as the digital revolution and innovations cannot be stopped in the field of sports and sports pedagogy either.

Sports analytics and sports informatics have grown to be an independent branch of the informatics sector demonstrated by the variety of devices including the odometers, pulse meters, mobile applications and sensors fulfilling analytical, support, and assistance functions. Accordingly, as in case of other subjects the integration of digital devices in P.E. classes appears to be inevitable.

Previous research in the field of laptops, tablets (JUNIU, 2011; LEIGHT, 2012), devices measuring physical activity (McCAUGHTRY et al. 2008), online activities (MARTIN, BALDERSON, and MORRIS, 2012; MCNEILL, MUKHERJEE and SINGH, 2010), and motion based or kinetic video games (ENNIS, 2013) focused on the application of such approaches in P.E. classes. Furthermore, researchers explored the application of ICT devices including Polar systems and Polar watches in P.E. classes as well. Such devices are suitable for the assessment of the intensity of the physical exertion level of students facilitating objective assessment on the part of the instructors (NAGY et al. 2017). International research also focuses on the application of odometers in P.E. lessons. Accordingly, it was shown that walking with an odometer increases the intensity of the respective physical activity, along with its frequency and duration (DUNN, L.- TANNEHILL, D, 2005, JANE M. SHIMON. - LINDA M. PETLICHKOFF, 2009, CHARLES F. MORGAN Jr et al. 2013). Having surveyed the relevant research results in Hungary we can conclude that apart from the application of ICT and e-Learning materials in teacher training (KOKOVAY, 2006, 2008; TÍMÁR, KOKOVAY, KÁRPÁTI 2011; BUCSY and SIMON 2008) no inquiry was performed in empirical device use. Yet, P.E. teachers in Hungary are required to perform tasks and fulfil expectations related to ICT use.

One such task is the mandatory National Uniform Learner Fitness test (NETFIT) whose results have been explored by several researchers (CSÁNYI et al. 2015, ERDEI 2015, NAGY et al. 2018). Consequently, all P.E. teachers are required to assess the motor skills and body profile of all students every year and the given data have to be uploaded into an electronic system. It is obvious that the fulfilment of this task requires ICT competences. Furthermore, the chapter on Physical Education in the Guide to the evaluation system of pedagogues specifies that P.E. teachers take advantage of the options provided by ICT devices including the GPS-based geo-location applications, the use of Polar watches, on-line practice design and on-line training diaries in addition to keeping pace with the digital educational materials and contents (https://www. oktatas.hu/pub_bin/dload/pem/testneveles_k_masodik_kieg. pdf). Moreover, if possible, digital educational materials and contents have to be used in the given lessons as well. At the same time all eight competences required of teachers have ICT-related components taken into consideration during performance evaluation.

Therefore, it can be concluded that Hungarian P.E. teachers are required to be familiar with and apply ICT devices. The respective intensity is determined by the theoretical and practical background of the given pedagogue along with the personal attitude and available infrastructure (BUDA, 2007). Emerging dialogue within the field suggests the potential implications of technology-enhanced pedagogy in terms of instructional practice, student learning, and solving pedagogical and instructional challenges (CASEY, GOODYEAR, and ARMOUR, 2017). Several recent studies have suggested favorable outcomes for technology-enhanced PE environments on student variables such as motivation and knowledge (LEGRAIN, GILLET, GERNIGON, and LAFRENIERE, 2015) and physical activity (PA) levels in classroom settings (MELTON, BLAND, HARRIS, KELLY, and CHANDLER, 2015). Nonetheless, widespread use of technology in PE classrooms remains limited and is primarily for management or communication (JUNIU et al., 2013; KRETSCHMANN, 2015). However gender, computer literacy, household computer ownership, and professional experience (years and service) influence physical education teachers views to different degrees. (KRETSCHMANN, R.2015) Thus, we believe it is essential to examine the attitudes and opinions related to the use of modern digital 
devices held by the next generation of sport pedagogues and potential P.E. teachers. Such unprecedented inquiry fulfils a gap filling function as the ICT-related attitudes of future P.E. teachers have not yet been assessed. Our research focused on the following issues:

1. What attitudes due students applying to P.E. teacher training programs maintain regarding the use of ICT devices?

2. Can a correlation be discerned between the sex and the attitude of prospective students?

\section{MATERIALS AND METHODS}

The research effort took place at the Institute of Sports Science of the Eszterházy Károly University. The research sample included applicants to P.E. teacher training programs in the 2016/17 and 2017/18 academic years. The total sample included 130 people with $83(63,8 \%)$ full time and 47 (36, $2 \%)$ part time students. The age of the participants ranged from 18 to 56 with the average age of 21,79 . $(\mathrm{SD}=5,50)$. The sample included 91 men $(70 \%)$ and 39 women (30\%). The study utilised the CAS or Computer Attitude Scale developed by Papanastasious and Angeli (2008). The given tool evaluates the beliefs and attitudes related to the educational application of the computer and the Internet. The continuum included 15 items to be ranked according to the Likert scale ranging from 1 (fully disagree) to 4 (fully agree). At the beginning of the research effort the scale was translated to Hungarian and English speaking teachers and experts fluent in the Hungarian language reviewed it. The respective data was processed by the 23.0 version of the IBM SPSS program package. The significance level was established at the margin of error used in social sciences $(p<0,05)$. The comparison of the respective groups was performed via a two sample $T$ probe and discriminant analysis or the stepwise method was used to explore those variables that greatly determine the differences between groups of men and women. The criteria for discriminant analysis were met.

\section{RESULTS AND DISCUSSION}

The data received via the application of the Computer Attitude Scale were divided into two groups after processing. Table 1 shows the statements related to computer assisted learning. The table doesn't display significant difference in replies to the given statements according to the respondents' sex. The highest attitude value for men $($ mean $=3,60)$ and women (mean $=3,49)$ was related to the statement: „I feel comfortable with the idea of the computer as a tool in learning." Furthermore, similarly to the previous question, both sexes consider the computer as a valuable device for learning as it is expressed by the sentence: „The computer is a valuable tool for students." The respective values for men were $m=3,46$ and for women $m=3,33$. The third highest average value was posted regarding the assertion: "The computer helps students learn in more effective ways" with $\mathrm{men}$ at $\mathrm{m}=3,36$ and women at $\mathrm{m}=3,33$. Furthermore, in case of statements with a negative connotation both men and women showed lower average or mean values. Thus the responses to such claims as "The computer is not conducive to good learning because it creates technical problems" and "The computer helps me learn because it allows me to express my thinking in better and different ways" can be assessed or evaluated in a positive light.

Table 1. .Gender and Attitudes towards Computer Use

\begin{tabular}{|c|c|c|c|c|c|}
\hline Attitudes & Gender & Mean & $\begin{array}{c}\text { Std. } \\
\text { Deviation }\end{array}$ & t-value & Sig. \\
\hline \multirow{2}{*}{$\begin{array}{l}\text { 1.I feel comfortable } \\
\text { with the idea of the } \\
\text { computer as a tool in } \\
\text { learning. }\end{array}$} & male & 3,60 & ,555, & \multirow[t]{2}{*}{1,051} & \multirow[t]{2}{*}{,295 } \\
\hline & female & 3,49 & ,644 & & \\
\hline \multirow{2}{*}{$\begin{array}{l}\text { 2.The use of com- } \\
\text { puters in learning } \\
\text { activities prevents } \\
\text { me from getting } \\
\text { stressed }\end{array}$} & male & 2,30 &, 863 & \multirow[t]{2}{*}{1,945} & \multirow[t]{2}{*}{, 054} \\
\hline & female & 1,97 &, 873 & & \\
\hline \multirow{2}{*}{$\begin{array}{l}\text { 3.I am skeptical of } \\
\text { the idea of learn- } \\
\text { ing and using a } \\
\text { computer. }\end{array}$} & male & 1,81 &, 802 & \multirow[t]{2}{*}{,- 192} & \multirow[t]{2}{*}{, 848} \\
\hline & female & 1,85 & 1,089 & & \\
\hline \multirow{2}{*}{$\begin{array}{l}\text { 4. The use of the } \\
\text { computer as a learn- } \\
\text { ing tool excites me }\end{array}$} & male & 2,64 & ,863 & \multirow[t]{2}{*}{,- 765} & \multirow[t]{2}{*}{,446 } \\
\hline & female & 2,77 & ,986 & & \\
\hline \multirow{2}{*}{$\begin{array}{l}5 . \text { The computer is } \\
\text { a valuable tool for } \\
\text { students }\end{array}$} & male & 3,46 & ,620 & \multirow[t]{2}{*}{1,019} & \multirow[t]{2}{*}{,310 } \\
\hline & female & 3,33 &, 737 & & \\
\hline \multirow{2}{*}{$\begin{array}{l}\text { 6. The computer } \\
\text { will change the way } \\
\text { I learn }\end{array}$} & male & 2,55 & ,806 & \multirow[t]{2}{*}{, 375} & \multirow[t]{2}{*}{,708 } \\
\hline & female & 2,49 & ,997 & & \\
\hline \multirow{2}{*}{$\begin{array}{l}\text { 7.The computer } \\
\text { helps me understand } \\
\text { concepts in more } \\
\text { effective ways }\end{array}$} & male & 3,27 & ,668 & \multirow[t]{2}{*}{,132 } & \multirow[t]{2}{*}{,895 } \\
\hline & female & 3,26 &, 850 & & \\
\hline \multirow{2}{*}{$\begin{array}{l}\text { 8.The computer } \\
\text { helps me learn be- } \\
\text { cause it allows me to } \\
\text { express my thinking } \\
\text { in better and differ- } \\
\text { ent ways }\end{array}$} & male & 2,92 & ,859 & \multirow[t]{2}{*}{,- 468} & \multirow[t]{2}{*}{,641 } \\
\hline & female & 3,00 & ,858 & & \\
\hline \multirow{2}{*}{$\begin{array}{l}\text { 9.The computer helps } \\
\text { students learn in } \\
\text { more effective ways }\end{array}$} & male & 3,36 & 641 & \multirow[t]{2}{*}{, 236} & \multirow[t]{2}{*}{, 814} \\
\hline & female & 3,33 & ,662 & & \\
\hline \multirow{2}{*}{$\begin{array}{l}\text { 10.The computer } \\
\text { is not conducive } \\
\text { to good learning } \\
\text { because it creates } \\
\text { technical problems }\end{array}$} & male & 1,63 &, 784 & \multirow[t]{2}{*}{,- 781} & \multirow[t]{2}{*}{,436 } \\
\hline & female & 1,74 & ,785 & & \\
\hline
\end{tabular}


Table 2 describes opinions regarding computer use. Significant sex-based difference was found in relating to the statement: „If something goes wrong with the computer, I know how to fix it" $(t=3,205, p<0,05)$. The mean value of "I can do what the computer can do as well" was $\mathrm{m}=1.92$ for women and $\mathrm{m}=1.82$ for men. "The use of computers scares me" and "I do not use computers because they are not easy to use" posted lower average values both for men and women alike.

Table 2. Gender and Attitudes towards Computer Use

\begin{tabular}{|c|c|c|c|c|c|}
\hline Attitudes & Gender & Mean & Std. Deviation & $\mathrm{t}$-value & Sig. \\
\hline \multirow{2}{*}{$\begin{array}{l}\text { 1.If something goes } \\
\text { wrong with the } \\
\text { computer, I know } \\
\text { how to fix it }\end{array}$} & male & 2,37 &, 839 & \multirow[t]{2}{*}{3,205} & \multirow[t]{2}{*}{, 002} \\
\hline & female & 1,87 &, 767 & & \\
\hline \multirow{2}{*}{$\begin{array}{l}\text { 2.The use of } \\
\text { computers scares } \\
\text { me }\end{array}$} & male & 1,26 &, 680 & \multirow[t]{2}{*}{$-1,173$} & \multirow[t]{2}{*}{,243 } \\
\hline & female & 1,44 & ,940 & & \\
\hline \multirow{2}{*}{$\begin{array}{l}\text { 3.I can do what the } \\
\text { computer can do } \\
\text { equally as well }\end{array}$} & male & 1,82 &, 838 & \multirow[t]{2}{*}{,- 573} & \multirow[t]{2}{*}{, 567} \\
\hline & female & 1,92 & 1,036 & & \\
\hline \multirow{2}{*}{$\begin{array}{l}\text { 4. I do not use } \\
\text { computers because } \\
\text { they are not easy } \\
\text { to use }\end{array}$} & male & 1,40 &, 828 & \multirow[t]{2}{*}{,- 709} & \multirow[t]{2}{*}{, 480 } \\
\hline & female & 1,51 & ,942 & & \\
\hline
\end{tabular}

Stepwise discriminant analysis on gender group revealed that three subscales were used in the discriminating model ("If something goes wrong with the computer, I know how to fix it", "the use of computers in learning activities prevents me from getting stressed", "the use of the computer as a learning tool excites me") with a total accuracy of $71.5 \%$. Table 3. proves that it is worthwhile keeping the function in the calculations.

Table 3. Discriminant analysis. Gender and Attitudes towards Computer Use Wilk's Lambda (Wilks' Lambda)

\begin{tabular}{|l|l|l|l|l|}
\hline $\begin{array}{l}\text { Test of } \\
\text { Function (s) }\end{array}$ & $\begin{array}{l}\text { Wilks' } \\
\text { Lambda }\end{array}$ & Chi-square & $\mathrm{df}$ & Sig. \\
\hline 1 & .886 & 15,326 & 3 & .002 \\
\hline
\end{tabular}

\section{CONCLUSION}

The primary objective of our research was to explore and assess the attitudes of applicants to P.E. teacher training programs to the use of ICT devices along with identifying the correlation between the sex and attitudes of the respondents. Previously disseminated international research has confirmed that the attitude of students majoring in P.E. and sports science can be influenced by several factors, especially the sex of the given participants (YAMAN, 2007; BEBETSOS and ANTONIOU, 2009). While our inquiry can conclude that both sexes maintain a positive attitude toward the use of infocommunication devices, contrary to the findings of GOKTAS (2012) men have a more positive attitude than women. The number of men stating that they could successfully address problems related to computer use was significantly higher than that of women. This can be explained by the better ICT skills of men and the fact that they use computers more in their free time than women do (HAKKARAININ et al. 2000; PAPASTERGIOU and SOLOMONODOIU, 2005). Trends related to men indicate that they are less afraid of using the computer and the educational application of computers can decrease their stress level more than that of women. Women, however, prefer to perform the functions of the computer themselves. Although our research results substantiate the findings of PALAIGEORGIOU et al. (2005) concerning a high level of commitment to computers both among men and women. Women tend to be more apprehensive regarding the use of hardware than men. Based upon our research we can make the following recommendations. Bolstered by the positive attitudes of applicants to P.E. teacher training programs students must be provided appropriate methodological preparation for the use of ICT devices both in school and in extracurricular settings in addition to teaching the use of the given technology. Accordingly, assigning priority to the educational application of ICT devices (educational software, applications, games) in P.E. and sports science subjects can enable students to gain direct, hands-on experience. Moreover, while increased use of ICT in teacher training programs can result in much desired perspective changes, the realization of this objective requires appropriate infrastructure and training formats.

Further research efforts should include a higher sample population via the inclusion of other institutions providing P.E. teacher training programs along with the respective students. This way a more profound or comprehensive picture can be gained concerning attitudes to ICT use. We believe that the research should be extended to instructors as well since the attitudes and device use of the latter can greatly determine the way students relate to technology. In the same vein the inclusion of in-service P.E. teachers would facilitate the exploration of the attitudes of various generations.

\section{ACKNOWLEDGMENTS}

The publication was supported by EFOP-3.6.2-16-201700003. The project was funded by the European Union, cofinanced by the European Social Fund. 


\section{REFERENCES}

Albirini A. (2006): Teachers' Attitudes toward Information and Communication Technologies: The Case of Syrian EFL Teachers. Computers \& Education, 2006; 47 (4), 272-398.

Bácsné, B. É.; Müller, A.; Molnár, A.; Dobay, B.; Bács, Z.; Pető, K. (2018a): Tourism Volunteering and sport TourismVolunteering and Sport - Connections and Implications from a research.Acta Oeconomica Universitatis Selye 7: 2 pp. 19-33. Paper: $1338-6581,15$ p. (2018)

Bácsné B. É; Bács Z.; Petô K.; Müller A.; Pfau C.; Dajnoki K.; Molnár A. (2018b): Önkéntesség a sportban. international journal of engineering and management sciences / múszaki és menedzsment tudományi közlemények 3: 5 pp. 217-230.

Baylor A., Ritchie D., (2002): What factors facilitate teacher skill, teacher morale, and perceived student learning in technologyusing classrooms? Computers \& Education, 2002; 39 (1), 395414.

Bebetsos E., Antoniou P. (2009): Gender differences on attitudes, computer use and physical activity among Greek university students, The Turkish Online Journal of Educational Technology - TOJET 2009; 8 (2), 63-67. ISSN: 1303-6521. Permanent link this document: http://www.tojet.net/articles/v8i2/826.pdf

Blurton C. (1999): New directions of ICT-use in education.

Bucsy G., Simon I. (2008): E-learning tananyag fejlesztés hatása az óvodai testnevelés gimnasztika mozgásanyagának elsajátítására. In: Kereszty, O. (szerk.) Új utak, szemléletmódok, módszerek a pedagógiában. Kaposvár, Magyarország: Kaposvári Egyetem, 2008. 33-39.

Buda A. (2007): Az infokommunikációs technológiák és a pedagógusok. Iskolakultúra 2007/4, 8-13.

Casey, A., Goodyear, V.A., \& Armour, K.M. (2017). Digital technologies and learning in physical education pedagogical cases. New York, NY: Routledge.

Charles F., Morgan Jr., Robert P. P., Aaron B. (2013): Using Pedometers to Promote Physical Activity in Physical Education, Journal of Physical Education, Recreation \& Dance,2013, 74 (7), 33-38, DOI: 10.1080/07303084.2003.10609235

Csányi, T., Finn J. K, Welk J. G., Zhu. W., Karsai I., Ihász F., Vass Z., Molnár L. 82015): Overview of the Hungarian National Youth Fitness Study. Res Q Exerc Sport. 2015; 86 (1): 3-12. doi: 10.1080/02701367.2015.1042823 (2015)

Czeglédi L. (2011): Minőségmenedzsment. Eger: EKF (2011), 127 p. Permanent link this document: https://www.tankonyvtar. $\mathrm{hu} / \mathrm{hu} /$ tartalom/tamop425/0005_42_minosegmenedzsment_ pdf/42_minosegmenedzsment_1_ 1. html

Dauvarte, L. (2015): Teacher's ICT Competence in Home Economics and Technologies Lessons. In Rural Environment. Education. Personality. (REEP). In: Proceedings of the International Scientific Conference (Latvia). 2015, may 15-16, Jelgava, Latvia, 2015: 89-100.

Dunn L., Tannehill D. (2005): Using Pedometers to Promote Physical Activity in Secondary Physical Education, Strategies, 2005; 19:1, 19-25, DOI:10.1080/08924562.2005.11000384

Ennis C. (2013): Implications of exergaming for the physical education curriculum in the 21 st century. Journal of Sport and Health Science, 2013/2, 152-157.
Erdei N. (2015): Sajátos nevelési igényű (SNI) és többségi tanulók testalkati mutatóinak és motoros képességeinek összehasonlító vizsgálata a NETFIT rendszerben. Különleges Bánásmód, 2015; I. évf. 2015/3. 57-66. DOI 10.18458/KB.2015.3.57

Goktas, Z. (2012): Techtrends tech trends. 2012; 56 (2), 22-30. https://doi.org/10.1007/s11528-012-0560-x

Hakkarainen K., Ilomaki L., Lipponen L., Muukonen H., Rahikainen M., Tuominen T.(2000). Students' skills and practices of using ICT: results of a national assessment in Finland. Computers and Education, 2000; 34, 103-117.

https://www.oktatas.hu/pub_bin/dload/pem/testneveles_k masodik_kieg.pdf (retrived: $2 \overline{0} 19.01 .29)$

Jun-Hyung Baek, Emily Jones, Sean Bulger, Andrea Taliaferro: Physical Education Teacher Perceptions of Technology-Related Learning Experiences: A Qualitative Investigation (2018) Journal of Teaching in Physical Education. Apr2018, Vol. 37 Issue 2, p175-185. 11p.

Juniu S. (2011): Pedagogical Uses of Technology in Physical Education. Journal of Physical Education, Recreation \& Dance, 2011; 82 (9), 41-49.

Juniu, S., Shonfeld, M., \& Ganot, A. (2013). Technology integration in physical education teacher education programs: A comparative analysis. Actualidades Investigativas Enducacio'n, $13,218-240$

Kokovay, Á (2006): Csak nem bukfencet akarsz tanítani számítógéppel?! Pedagógiai Múhely (Nyíregyháza), 2006; 34: 4 pp. 25-40.

Kokovay, Á: (2008): IT (Információs Technológia) alkalmazása a sportszakember képzésben. Magyar Sporttudományi Szemle, 2008; 9: 3 (35) pp. 31-33.

Koltay T (2010): “Az új média és az írástudás új formái.” Magyar pedagógia. 2010; 110.(4) : 301-309.

Kretschmann, R. (2015). Physical Education Teachers' Subjective Theories about Integrating Information and Communication Technology (ICT) into Physical Education. The Turkish Online Journal of Educational Technology, 14 (1), 68-96.

Lai K. W., Pratt, K. (2004): Information and communication technology (ICT) in secondary schools: the role of the computer coordinator. British journal of educational technology, 2004; 35 (4), 461-475

Leight J. (2012): Technology for Physical Education Teacher Education: Student Handbook of Technology Skills Instruction \& Assessment. Create Space Independent Publishing Platform. 2 nd edition, 2012;129.p. ISBN-13: 978-1494895761.

Markos, V. ; Tóth, D.A.; Kocsis, I.; Máthé, E.; Juhász, C. ; Bácsné, B. É.; Fenyves, V. (2017): A Debreceni Egyetem Gazdaságtudományi Karának Controlling és teljesítmény menedzsment szakirány kurzusainak értékelése.International Journal of Engineering and Management Sciences / Múszaki és Menedzsment Tudományi Közlemények 2 : 2 pp. 100-107.

Martin M., Balderson D., Morris M. (2012): Using an Online Learning- Management System for Coaching. Journal of Physical Education, Recreation \& Dance, 2012; 83 (4), 50-56.

Máté, D.; Fenyves, V. (2016): A foglalkoztatás regionális kérdései a tudás-intenzív üzleti szolgáltatásokat nyújtó ágazatokban a Kárpát-medencei országok összevetésében.TAYLOR: Gazdálkodás- És Szervezéstudományi Folyóirat: A Virtuális Intézet Közép-Európa Kutatására Közleményei 8 : 5 pp. 5-13. 
McCaughtry N., Oliver K. L., Dillon S. R., Martin J. J. (2008): Teachers' Perspectives on the Use of Pedometers as Instructional Technology in Physical Education: A Cautionary Tale. Journal of Teaching in Physical Education, 2008 ; 27 (1), 83-99.

McNeill M., Mukherjee S., Singh G. (2010): Podcasting in Physical Education Teacher Education. ICHPER-SD Journal of Research, 2010; 5 (1), 16-19.

Molnár Gy. (2011): Az információs kommunikációs technológiák hatása a tanulásra és oktatásra Magyar Tudomány, 2011; 172 (9), 1038-1047

Nagy Zs., Laoues C.N., Müller A. (2018): A szocioökonómiai háttérváltozók szerepe a NETFIT mérésben. Különleges bánásmód , 2018; 4: 4 pp. 33-44.

Nagy Zs., Müller A., Bácsné B.É., Bíró M., Pusztai G. (2017): A differenciálás mérése a testnevelésben az atlétika tanítási egység alatt. Képzés és Gyakorlat: Training and Practice, 2018; 15: 4 pp. 147-162.

Palaigeorgiou G. E., Siozos P. D., Konstantakis N. I., Tsoukalas I. A. (2005): A computer attitude scale for computer science freshmen and its educational implications. Journal of Computer Assisted Learning, 2005; 21 (5), 330-342.

Papanastasiou E. C., Angeli C. (2008): Evaluating the use of ICTs in education: psychometric properties of the survey of factors affecting teachers teaching with technology (SFA-T3). Educational Technology and Society, 2008; 11 (1), 69-86.

Papastergiou M., Solomonidou C. (2005): Gender issues in Internet access and favourite Internet activities among Greek high school pupils inside and outside school, Computers and Education, 2005; 44, 377-393.

Pineida F. O. (2011): Competencies for the 21st Century: Integrating ICT to Life, School and Economical Development. Social and Behavioral Sciences, 2011; 28, 54-57.

Shimon J. M., Petlichkoff, L. M. (2009): Impact of pedometer use and self-regulation strategies on junior high school physical education students' daily step counts. Journal of Physical Activity and Health, 2009; 6(2), 178-184.

Tarnóczi, T.; Bács, Z.; Böcskei, E.; Fenyves, V. (2017): Mérlegen (Kívül) a tudásalapú gazdaság - Az intellektuális tôke mérésének relevanciája.Controller Info 5 : klsz pp. 303-320.

Tearle P. (2003): ICT implementation: What makes the difference?. British Journal of Educational Technology, 2003; 34 (5), 567-583.

Tímár S., Kokovay Á., Kárpáti A.(2011): Testnevelés tanítása YouTube-bal: pedagógiai érték a társadalmi médiában. In: Kozma, Tamás; Perjés, István (szerk.) Új kutatások a neveléstudományokban 2010: törekvések és lehetôségek a 21. század elején. Budapest, Magyarország: ELTE Eötvös Kiadó, 2011; pp. 22-36. , 15 p.

Yaman M. (2007): The attitudes of the physical education students towards The Internet, The Turkish Online Journal of Educational Technology - TOJET . 2007; 6 (3), 79-88.p. ISSN: 1303-6521

Yuen A. H., Law N., Wong K. C. (2003): ICT implementation and school leadership: Case studies of ICT integration in teaching and learning. Journal of Educational Administration, 2003, 41 (2), 158-170. 